\title{
Competences in the knowledge-based economy
}

\author{
Jolanta Sala \\ Powiślański College, \\ ul. 11Listopada 13, 82-500 \\ Kwidzyn, Poland \\ Email: jolasala@interia.pl
}

\author{
Halina Tańska \\ University of Warmia and Mazury \\ in Olsztyn, ul. Słoneczna 54, \\ 10-689 Olsztyn, Poland \\ Email: tanska@uwm.edu.pl
}

\begin{abstract}
The article discusses the causes of the difficulties and contradictions associated with the management information systems referring to the competences of knowledge workers in organizations. As far as entities are concerned, the reasons are mainly the effects of global phenomena of socio-economic life. Unfortunately, with the increase in the declared need for competences in the knowledge-based economy, there are a growing number of knowledge workers without jobs and livelihood. Social inequalities are rising. At the same time, the productivity in enterprises is increasing, the profits are growing, and the wages are declining. Knowledge workers without stable jobs are the new dangerous class "precariat" of enormous magnitude. There are very serious threats which require solutions for the management of information systems referring to the competences of knowledge workers at all levels of socio-economic life.
\end{abstract}

\section{$\mathrm{T}$} he authors of this paper face difficulties with the identification [1], measurement, assessment and analysis of competences of knowledge workers on a daily basis, which universities struggle with. Competences of knowledge workers are also a challenge in other organizations, in particular in the commercial companies. A competence in the knowledge-based economy is a complex category based on three attributes: knowledge, skills and approaches adjusted to the situation (capabilities, personal, psychosocial and cognitive predispositions). A competence is often equated with qualifications. The problem of information systems in this context, has been signalled methodically by J. Oleński in 2000 [2], who has indicated the cause of standardization deficiencies in the system of national accounts SNA 93 and ESA 95. J. Oleński identified the paradoxes of information systems, which the authors of this study verified in their studies, and in particular since 2010 in enterprises in the Pomeranian Province. The aim of this study is to identify the most serious consequences of underdevelopment of information systems (ISM) in the context of competence.
Managing knowledge workers is not an easy task, and the topic is still present in some economic and social institutions, local and regional communities, and also on a national and global scale. The paper presents selected aspects of competences in the knowledge-based economy from the perspective of knowledge workers, who have become a part of the emerging social group called a precariat [3]. The precariat is a social group newly forming on the global scale, whose characteristics are so different from past experience, that not only in theory, but also in practice (managers and politicians) there is no understanding of its essence and size. The precariat create new requirements for IT systems referring to managing knowledge workers. In this paper, the authors synthetically present assumptions and main conclusions of the study, whose aim was to demonstrate on a small group the phenomenon of the lost human capital potential, not only in enterprises but also in the region due to the underdevelopment of information systems in the context of professional competence.

\section{ECONOMIC AND SOCIAL PROSPERITY}

The essence of the industrial economy was land, capital, labour (work) and its harmonious development was provided for example by reorganization of rules connected with working conditions. Labour is understood as human efforts made to produce the good along with the price, which is a wage. In the classical economics of A. Smith (1776) two other factors are land and natural resources owned by people (a price of land is a land rent) and capital understood as goods produced previously by people and used to the production of other goods - such as buildings, tools and machinery (the price of the capital is interest rate). The contemporary world entered the postindustrial economy based on globalization and information society - often called the knowledge-based economy - with the exposed factor of mental work (white-collar workers) focused on information and knowledge, which is shown in the Figure 1. 


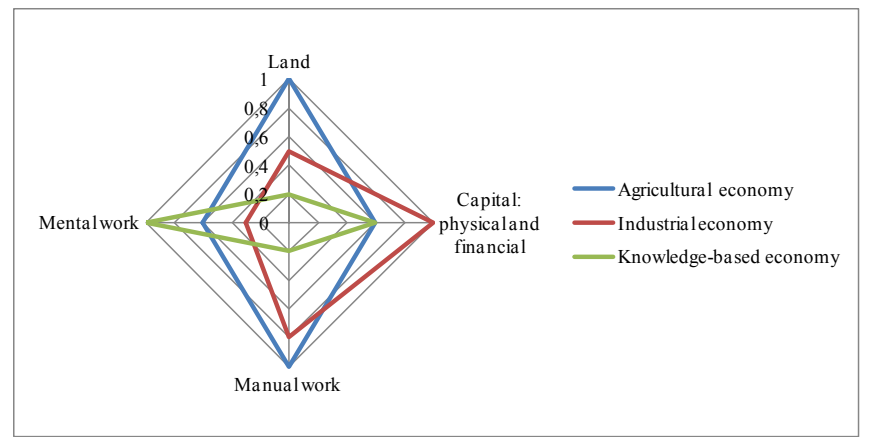

Fig. 1 The comparative interpretation of agricultural, industrial and knowledge-based economies [own research]

There have been significant changes in existing rules connected with work management and organization. For instance, enormous expectations were linked to the flexible forms of employment, which consequently required elaboration of the safety rules - flexicurity. Studies conducted by economists and sociologists, including $\mathrm{J}$. Stiglitz [4], M. Castells [5], J. Dijk [6], revealed many negative implications of the existing changes. M. Castells formulated a diagnosis of consequences of ICT technologies as ten processes [7, pp. 60-64]: rising inequalities and social exclusion all over the world (process 1), appropriation of the wealth generated by collective effort (process 2), four processes connected with the relationships of distribution/consumption, i.e. inequality, polarization, poverty, misery, as well as four processes connected with relationships of production, i.e. individualization of work, over-exploitation of workers, social exclusion, perverse integration.

The negative implications referring to the impact of ICT technologies identified by M. Castells have been confirmed by G. Standings' conclusions on changes taking place in the social class structure. Standing has identified a new social group 'precariat', presented in Figure 2.

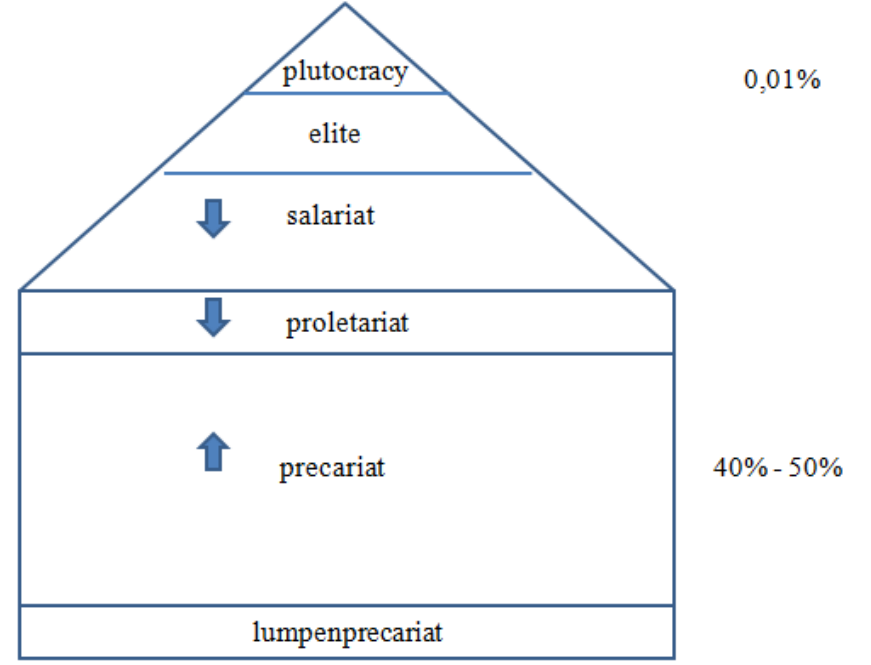

Fig. 2 The new hierarchy of class structure of the adult population of society emerging as a result of globalization according to G. Standing [8]
According to G. Standing [8], at the top of the hierarchy there is a plutocracy, and below are elite, a salariat, a proletariat, a precariat and a lumpenprecariat. Plutocracy are $0,01 \%$ of the richest people, hundreds of people, who own the capital worth approximately $20-40$ billion USD, and at the top of this group there are people owning 80-90 billion USD! They have great power, mightiness, they can have impact on media, sponsor politics and fund political parties. Elite can be distinguished by huge capital gains and whereas Salariat is characterised by stable employment, high salaries, access to capital gains, variour benefits, pension schemes, etc. Proletariat is disappearing all over the world; Precariat is a newly emerging social group. Lumpenprekariat are people expelled from society, suffering from different types of mental disorders, homeless, isolated.

According to G. Standing's estimates [9], the precariat accounts for above $40 \%$ of adult population of societies in the developed countries, and according to studies conducted in Japan - over $50 \%$ are a group of precarians, i.e. people deprived of stable employment and doomed to have a job below their level of educational qualifications. The social group 'precariat' is defined in three dimensions [3]: relationships of production, relationships of distribution, political relationships. The precariat has been spreading and growing at a faster pace since the crisis in the year 2008 as a result of the policy of austerity measures and budget cuts. Employers take the opportunity to reduce costs through a deterioration of working conditions. Sadly, knowledge workers account for a large part of the precariat, which is not a good sign of development of the knowledge-based economy [10].

The authors [11] have attempted to identify the prosperity in context of labour and tools, crucial for fulfilling the task, which has been recently noted by Poles seeking the job. The authors have distinguished seven phenomena of social and economic life in Poland and with the help of those phenomena they showed the main weak points of work processes. The authors have exposed the neglects connected with the relation of work and ICT tools as the vital foundation of building the prosperity in XXI century.

On the one hand worldwide and Polish experiences still bring negative outcomes, but on the other hand there is a search for the transformation of society and the transformation of organizations with ,human face" and reflecting capabilities and the potential of new technologies. The achievements of Scandinavian countries, such as Finland and Sweden in particular, are often presented as the example of economic and social prosperity.

\section{COMPETENCES FRAMEWORK AND QUALIFICATIONS FRAMEWORK}

In times of the knowledge-based economy more than 135 countries have decided to introduce qualifications framework (QF), also the EU countries have been involved in the EQF. Qualifications framework systematises knowledge, skills, 
approaches and is based on two dimensions of the competences: general education and vocational education. Polish qualifications framework (PQF) comprises eight levels. The graph in the Figure 3 presents a synthetic interpretation of relationships between both dimensions. Because of the substantial collapse of formal vocational education in Poland one can say, that general education has formal character (the Y-axis), and vocational education non-formal and informal (the X-axis). Although the graph was constructed on the basis of studies conducted in Poland, its interpretation is universal.

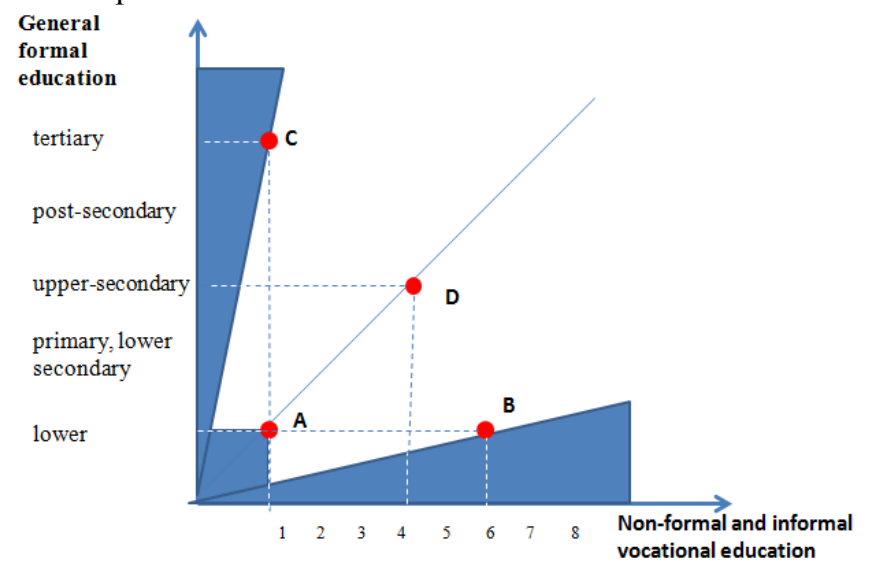

Fig. 3 Relationships of identified cases in the Polish education system [own research]

The point $\mathrm{A}$ in Figure 3 (and the area it belongs to) describes a relatively small group of workers, just like the point B. However, a large group of workers and potential workers, particularly young ones, are represented by the point C. Obviously, the point $\mathrm{D}$ is ideal in terms of effectiveness, balancing theoretical and practical potential. It can be assumed, that while moving upwards a diagonal, scribed by points $\mathrm{AD}$, the importance (value) of a worker is increasing for the knowledge-based economy.

The analyses, which are being conducted by the Polish Ministry of Digital Affairs, have led to the elaboration of a very useful model of digital competences, which are the central attribute of key competences for the knowledgebased economy [12]. According to the EU [13], key competences are those, which all people need for fulfilment and personal development, being an active citizen, social integration and employment. The following eight key competences have been established: (1) communication in the mother tongue; (2) communication in foreign languages; (3) mathematical competence and basic competences in science and technology; (4) digital competence; (5) learning to learn; (6) social and civic competences; (7) sense of initiative and entrepreneurship; (8) cultural awareness and expression. The relational model [12] was identified on the three levels of digital competences: IT, information and functional. As a result, the framework catalogue of digital competences was prepared, which might be the reference point for activities aimed at providing and enhancing digital competences. An important assumption of the catalogue is the connection between the digital competences and the users' needs and the benefits that they may gain in key areas of life.

\section{TRANSFORMATION OF ORGANIZATIONS}

In case of a university - which is an interdisciplinary and multifunctional organization - management of knowledge workers is often passive, random or discretionary. Sadly, it does not foster creativity, and undoubtedly is dominated (overwhelmed) by bureaucratic rules. A lot of expectations are based on internal quality management systems in education and other rules of workers assessment. There are various concepts regarding management of knowledge workers in companies, who see their opportunity in transformation and gaining competitive advantage for example by taking part in digital industrial revolution [14], [15] or affirmation of idea "Industry 4.0".

A proposal of the approach to the individual evaluation of a knowledge worker was presented in the paper [16] and is worth considering. It is focused on developing a profile of an engineer (automation service engineer, computer scientist or ITmatician) in the context of eight dimensions of quality: effectiveness, functionality, reliability, durability, compliance with standards, "supportability", aesthetics, "perceived quality". Although assumptions of the approach by [17] seem to be controversial, but, undoubtedly, the direction of adjusting quality of job carried out by knowledge worker to needs and expectations of a customer is the proper one. The core of the approach is to deliver a tool supporting innovative projects for both parts, employers and contractors, in the form of a ,image of quality" presented in the Figure 4.

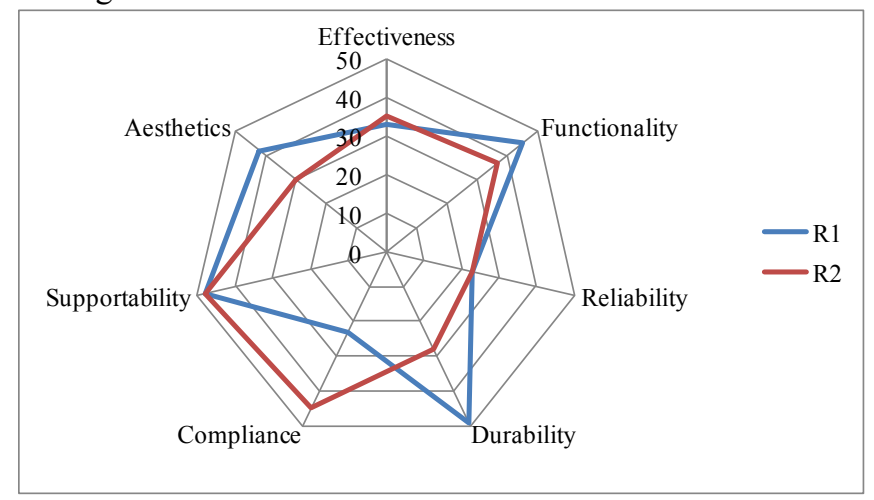

Fig. 4 „Image of quality” of knowledge workers competences from selected vocational groups [16]

The graph in the Figure 4 shows seven dimensions of quality, which are universal for the area of knowledge represented by two sample solutions. Analyzing the eighth dimension - ,perceived quality” - is recommended individually for each solution (project) or even for each person taking part in the project. With this tool a contractor of the solution R1 and/or R2 has the support before making 
irresponsible promises (mainly due to the possession of an ,image of quality" regarding competences of knowledge workers acting as sellers and performers). Similarly for employers, taking a look at competences of companies (through knowledge workers representing them) who offer both solutions is a useful ,image of quality" for a planned innovation.

The authors considered this tool aspect, defining (identifying) knowledge cage for project teams [18] and trying to analyze a "pig in a poke" syndrome ("cat in the sack" syndrome) [19]. Not only the knowledge-based economy, but also information society needs this type of tools, although their practical usage is a long-term process. A good example are difficulties connected with evaluating intellectual capital of companies and applying to them generally accepted accounting principles, which is described with determination in publications written by i.a. L. Niemczyk [20].

The identification and analysis of information gap does not lose its instrumental up-to-date character, including competence gaps, which the authors focused on in studies and many publications, for example [21]. However, due to dynamic changes and development of science and technology in social and economic life there is non-trivial problem regarding the model for identifying gaps, and the risk of uncritical trust in models. Many companies and a lot of their workers recorded losses in a long-term perspective, which had been caused by affirmation of flexible forms of employment providing short-term gains. Life begins to be consumed by the work/activity.

Attempts aimed at moderating the knowledge-based economy in the EU have led to the rule of forming "intelligent specializations" for countries and regions.

\section{V.THE WORKING CONDITIONS AND TRANSFORMATION IN POLAND}

Transformation in Poland after 1989 was also associated with the necessity of the creation of public employment services, which have matured to the role of socio-economic, along with the formation of the labor market. Parallel changes were subject to information systems for monitoring and evaluation of the labor market. Therefore it is worth noting synthetically the current state of information systems of Polish public employment services, although it would be interesting to apply the possibilities of a conversion method for the evaluation [22] and assess the quality of egovernment portals [23]. The authors focused on information as an economic resource, as a common good and as an economy infrastructure in line with the aspects approach of J. Oleński [2]. Despite the development of a new systems of national accounts SNA 2008 and ESA 2010 it is still not possible to classify the resources important for the knowledge-based economy.

The public information system for Polish employment services looks notably modest, although the progress is undoubtedly large. They are integrated and standardized different information systems, run by various entities, providing the Internet vortal [24]. From the perspective of the labor market the portal provides five "databases", including the classification of professions and specialties, and standards / professional competencies base and modular training programs. In addition, the portal also provides "statistics and analysis", but unfortunately only in two areas: the "registered unemployment" and "employment of foreigners in Poland". During the integration of information systems in the vortal there were ignored reports on "competition deficit and surplus" available only on the website of the Ministry of Family, Labour and Social Policy [25].

As to "strategies and programming documents" on the vortal there is a strategy for the development of human capital, which is a copy of the strategy "Europe 2020". Among the attachments three are two recent documents: "The project of the National Action Plan for Employment in the period 2015-2017" and " Program and organizational assumptions for preparation of the National Action Plan for Employment in the years 2015-2017". All program goals are grouped in the two following priority areas: increasing the efficiency of the management of the labour market in order to support the growth of employment and increase of adaptability of the labour market. Undoubtedly, this information system would need the risk analysis in accordance with the conclusions of [26], as well as the use of idea electronic communities published in [27].

The direction of changes which was indicated by G. Standing, resulting in the depreciation of knowledge workers who have been respected and successful in professional life so far, is also confirmed by consequences of restructuring of companies in Pomeranian (pomorskie) voivodeship at the turn of 2014 and 2015 year. The authors have conducted research based on 241 people $(20 \mathrm{~F} / 221 \mathrm{M})$, who experienced unexpected personal trauma. Virtually overnight, mainly engineering and technical workers found out, that their knowledge, skills and experience were worthless, regardless of their formal education ( $19 \%$ of whom were experienced employees with university degrees), which is shown at the graph in the Figure 5 (also regardless of their non-formal and informal education, qualifications, played roles and occupied positions - over $60 \%$ of them were highly qualified technicians).

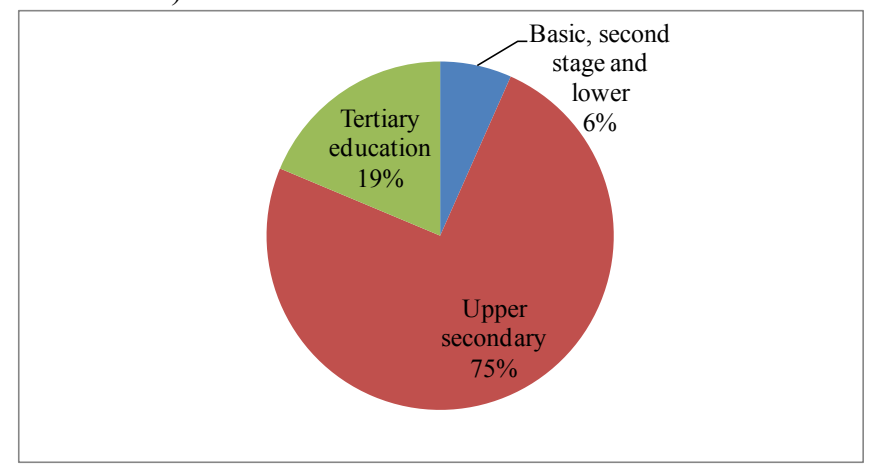

Fig. $5 \mathrm{~A}$ structure of the researched group by formal education [own research] 
Due to intervention of state institutions, people from the researched group could have tried to become entrepreneurs, starting their own companies with the financial support (grants) or acquire new qualifications, taking part in free trainings. Because of the transformation of companies $(92 \%$ of big enterprices) a group of the precariat has increased on the Pomeranian labour market, which does not mean that there has been an increase in the number of unemployed. The companies, in line with their own decisions, has lost their intellectual capital. The personal situation of employees made redundant for reasons attributable to the employers has deteriorated drastically, despite the state supportive intervention. The analyzed group of 241 people accounts for a part of wider studies which have been conducted by the authors, involving 2094 people, since the year 2010, and a phenomenon of the fast growing precariat is widespread. In the context of this fact, the knowledge-based economy and its main assumptions seem to be a utopia and require a fundamental revision.

Similar state intervention as in the Pomeranian Province were undertaken during the years 2007-2014 and are planned in the years 2014-2020 also in other provinces. During the study it was verified that this type of government intervention to increase the efficiency and adaptability of the labor market. However, emerging information resources were used mainly for the settlement of this business. Contractor of intervention was obliged to collect data in three information systems: PEFS 2007, monitoring of indicators and the Registry "employability".

The PEFS 2007 served in the years 2007 to 2014 in the records of the persons (people) receiving support from national and European funds (ESF). Monitoring of indicators was processed normally on a quarterly basis and served as quantitative reporting in 7 layouts (input-output, by employers, by age, by education and other specific indicators). Records of "employability" was used as a quantitative monitoring of two states employment of persons covered by the support i.e. at 3 months and 6 months after termination of support. Information resources of these systems were very dispersed and were only operating instruments although their potential was much greater.

There was probably an effort taken for the integration of the functionality of those three information systems into a single system SL2014, which the authors plan to verify in the terms of the range of information and support of decisionmaking processes in the context of professional competencies, the phenomenon of loss of human capital, and tackling the problem of the depreciation of precariat. Unfortunately, the research hypothesis is not optimistic, which is not a good anticipation for the development of knowledge-based economy. Development of the knowledgebased economy cannot be based only on companies but also on the added value of various state intervention, including similar to those covered by the research.

\section{CONCLUSION}

The knowledge-based economy in practice deviates significantly from the theoretical assumptions. Transformations taking place in organizations and countries have led to negative economic and social consequences.

What the studies confirm is that the level of economic and social prosperity has decreased significantly in the developed countries. The adverse effects of existing changes are heavily felt by educated people, who, in principle, were to be the pillar of the knowledge-based economy (Figure 1). The mental work - as the most crucial production factor - has relationships in production highlights the tendencies depreciating possibilities enabling to keep the pace of development for science, technologies and culture, e.g. the individualization of work. As a result, the economic and social situation of the new social class 'precariat' is deteriorating (Figure 2). According to G. Standing, for the first time in history of economics, the productivity is growing, capital gains are increasing, but salaries are decreasing.

For the organizations who are in the period of transition to the knowledge-based economy, the quality management is still a useful tool. The instrumental potential is still associated with the improvement of systems and information processes, i.e. information gap, competence gap, information asymmetry, etc. Thus, the information economics indicates directions in implementations of information systems supported by ICT technologies. Applications of ICT technologies, assisting various areas of managing organizations in transitions, are still pioneers and creators of directions of changes, strengthening the position of ICT industry. The industry does well with commercialization and marketing of its offers starting from the highest political levels (the latest examples are the fourth digital-industrial revolution and Internet of Things along with standards). Developing models and applying benchmarking is seen as crucial. There is a growing need for instruments of accounting, which evaluate intellectual capital.

With the alarming state of the knowledge-based economy in the context of precariat and complex situation on the labour market, companies have intensified their marketing efforts and raised interests in the applications enabling human resources management. The need ,lack of well qualified specialists" was identified as well as the set of solutions supported by ICT applications, including paying more attention to the development of already employed workers and the better matching workers to the positions. Thus, ,the competence mismatch, which results in the low effectiveness of workers" [28], has become a marketing argument for the implementation of advanced IT tools as the only antidote for large and medium enterprises.

It should be underlined that the issue of knowledge workers' productivity is not at the core of the current global collapse of the knowledge-based economy. If direct employers and indirect employers (state institutions) do not 
react in relatively fast and effective way to difficult, sometimes even dramatic economic and social situations of knowledge workers - who are pushed to the class of precariat, the development of the knowledge-based economy will be obstructed because of the depreciation of high competences, education and lifelong learning. Currently, a dramatic waste of the intellectual potential is continuing and is growing on the global scale. Managers and politicians are not able to manage intellectual capital and social capital, putting themselves first, while the scale and pace of enrichment is unimaginable. As far as Poland is concerned, the situation and conclusions are similar, although in many ways they reflect the specificity of the country.

\section{REFERENCES}

[1] I. Pawełoszek, "Semantic Organization of Information Resources for Supporting the Work of Academic Staff," Proceedings of the 2014 Federated Conference on Computer Science and Information Systems pp. 1235-1241, ACSIS, Vol. 2, DOI: 10.15439/2014F320

[2] J. Oleński, Elementy ekonomiki informacji, Katedra Informatyki Gospodarczej i Analiz Ekonomicznych, Uniwersytet Warszawski, Warszawa 2000.

[3] G. Standing, The Precariat. The New Dangerous Class, Bloomsbury Academic, London 2011

[4] J. E. Stiglitz, Szalone lata dziewięćdziesiąte, Wydawnictwo PWN, Warszawa 2006

[5] M. Castells, Społeczeństwo w sieci, Wydawnictwo Naukowe PWN, Warszawa 2008.

[6] J. Dijk, Społeczne aspekty nowych mediów. Analiza społeczeństwa sieci, Wydawnictwo Naukowe PWN, Warszawa 2010.

[7] M. Castells, Koniec tysiąclecia, Wydawnictwo Naukowe PWN, Warszawa 2009

[8] G. Standing, "The Precariat and Class Struggle," Revista Crítica de Ciências Sociais 103, May 2014, p.9-14.

[9] E. Koszowska, „Bezwarunkowy dochód podstawowy. Prof. Guy Standing: każdemu się należy," WP Opinie [on-line]. Grupa Wirtualna Polska S.A., 2015-10-21

[10] J. E. Stiglitz, Cena nierówności. W jaki sposób dzisiejsze podziały społeczne zagrażają naszej przyszłości, Wydawnictwo Krytyki Politycznej, Warszawa 2015.

[11] J. Sala and H. Tańska, „Dobrobyt w kontekście pracy i narzędzi pracy,” in Wydawnictwo Uniwersytetu Gdańskiego, Gdańsk 2015.

[12] J. Jasiewicz, M. Filiciak, A. Mierzecka, K. Śliwowski, A. Klimczuk, M. Kisilowska, A. Tarkowski and J. Zadrożny, Ramowy katalog kompetencji, MC, Warszawa 2015, https://mc.gov.pl/files/ramowykatalog-kompetencji-cyfrowych.pdf

[13] Zalecenie Parlamentu Europejskiego i Rady Unii Europejskiej nr 2006/962/WE z dnia 18 grudnia 2006 w sprawie kompetencji kluczowych w procesie uczenia się przez całe życie [Dz.U.L394 z 30.12.2006]

[14] A. Gąsiorek, „Cyfrowa rewolucja przemysłowa szansą na transformację i zdobycie przewagi konkurencyjnej," Control Engineering $\mathrm{nr} 2$ (118) 2016, Wydawnictwo Trade Media International, s. 127.

[15] M. Łopaciński and M. Matejczyk, „Transformacja organizacji - jak ją przygotować aby miała szansę powodzenia," Biznes i produkcja, nr 13 (2/2015), Wydawca ASTOR, s. 6-9.

[16] J. Gracel, „Jakość inżyniera ...,” Biznes i produkcja, nr 11 (2/2014), Wydawca ASTOR, s. 42-43

[17] D. A. Garvin, "Competing on the Eight Dimensions of Quality," Harvard Business Review, November-December 1987, pp. 101-109.

[18] J. Sala and H. Tańska, "The cage of knowledge in process of information systems development," in Computer Systems Engineering Theory \& applications, K. J. Burnham, L. Koszalka, Wrocław 2005, ISBN 83-911675-8-5, s. 157-167.

[19] J. Sala and H. Tańska, „Syndrom „kota w worku” w społeczeństwie informacyjnym," in Społeczeństwo informacyjne w świecie rzeczywistym i wirtualnym, A. Szewczyk (red.)], Zeszyty Naukowe Uniwersytetu Szczecińskiego, $\mathrm{nr}$ 656, Studia Informatica $\mathrm{nr} 28$, Szczecin 2011, s. 455-465.

[20] L. Niemczyk, Kapitał intelektualny w księgach rachunkowych oraz sprawozdawczości przedsiębiorstwa, Wydawnictwo Uniwersytetu Rzeszowskiego, Rzeszów 2015

[21] J. Sala and H. Tańska, "Tool dilemmas of innovation," Position papers of the 2014 Federated Conference on Computer Science and Information Systems pp. 265-269, ACSIS, Vol. 3, DOI: 10.15439/2014F484.

[22] W. Chmielarz and M. Zborowski, "The Application Of A Conversion Method In A Confrontational Pattern-Based Design Method Used For The Evaluation Of IT Systems," Proceedings of the 2014 Federated Conference on Computer Science and Information Systems pp. 12271234, ACSIS, Vol. 2, DOI: 10.15439/2014F198.

[23] E. Ziemba, T. Papaj and D. Descours, „Assessing the quality of egovernment portals - the Polish experience," Proceedings of the 2014 Federated Conference on Computer Science and Information Systems pp. 1259-1267, ACSIS, Vol. 2, DOI: 10.15439/2014F121.

[24] http://psz.praca.gov.pl.

[25] http://www.mpips.gov.pl/analizy-i-raporty/raporty-sprawozdania/rynek -pracy/zawody-deficytowe-i-nadwyzkowe/

[26] E. Ziemba and I. Kolasa, „Risk factors framework for information systems projects in public organizations - Insight from Poland," Proceedings of the Federated Conference on Computer Science and Information Systems pp. 1575-1583, ACSIS, Vol. 5, DOI: $10.15439 / 2015 \mathrm{~F} 110$

[27] C. Stepniak and T. Turek, „Levels of the Use of Electronic Communities in the Management of Regions," Proceedings of the Federated Conference on Computer Science and Information Systems pp. 1551-1556, ACSIS, Vol. 5, DOI: 10.15439/2015F277.

[28] M. Pawlik, ,,Tendencje na polskim rynku teleinformatycznym w 2015," Inżynieria \& utrzymanie ruchu, nr 1 (112), Wydawnictwo Trade Media International, 2016, s. 12-13. 